\title{
The Relationships among Entrepreneurial Characteristics, Entrepreneurial Attitude, and Entrepreneurial Intention
}

\author{
Anik Kusmintarti ${ }^{1}$, Armanu Thoyib ${ }^{2}$, Khusnul Ashar ${ }^{3}$, Ghozali Maskie ${ }^{4}$ \\ ${ }^{1}$ Accounting Department, State Polytechnic of Malang, Indonesia \\ ${ }^{2}$ Faculty of Economics and Business, Brawijaya University, Malang, Indonesia \\ ${ }^{3}$ Faculty of Economics and Business, Brawijaya University, Malang, Indonesia \\ ${ }^{4}$ Faculty of Economics and Business, Brawijaya University, Malang, Indonesia
}

\begin{abstract}
The world has a big concern to entrepreneurship. The Indonesian government has been trying to increase the number of entrepreneurs by changing the way of thinking of college and university graduates from job seekers into job creators. One of the government's efforts to realize that programme is by launching Student Entrepreneur Program. The programme is aimed to facilitate students who have an interest in entrepreneurship and to start their businesses that are based on knowledge, science, and art.

This study aims to analyze the role of entrepreneurial attitude as a mediator of entrepreneurial characteristics influence on entrepreneurial intention. The population of this research are students of semester one to the last semester of State Polytechnic of Malang and Brawijaya University who have learned an entrepreneurial education. Judgment sampling is used to choose the sample. The data collection was done through questionnaires. The data were collected from 206 respondents. The collected data were analyzed by using descriptive statistical analysis and path analysis. The result shows that entrepreneurial attitude acts as a partial mediation of entrepreneurial characteristics influence on entrepreneurial intention.
\end{abstract}

Keywords: entrepreneurial characteristics, entrepreneurial attitude, entrepreneurial intention

\section{Introduction}

These days, the world has a big concern to entrepreneurship. A country with a lot of entrepreneurs has a potential to develop rapidly and will become prosperous (McClelland, 1961). The Indonesian government has been trying to increase the number of entrepreneurs by changing the way of thinking of college and university graduates from job seekers into job creators. One of the programmes done by the government to realize the programme is by launching Student Entrepreneur Program. The programme is aimed to facilitate students who have an interest in entrepreneurship and to start their businesses that are based on knowledge, science, and art (Directorate General of Higher Education, The Ministry of National Education, 2010).

Entrepreneurial intention is described as a cognitive representation of actions to be implemented by individuals to either establish a new independent ventures or to create new value within existing company ( Fini, Grimaldi, Marzocci, and Sobrera, 2009). This study describes entrepreneurial intention as a cognitive representation of actions that is implemented by someone to establish a new business. Entrepreneurial intention is influenced by a number of factors. One of them is characteristics. Previous researchers wrote some important characteristics that should be owned by someone that is chooce entrepreneurship as a career. Bird (1988) states that entrepreneurial intention is determined by two factors, entrepreneurial traits and environment. The description of entrepreneurial intention by Bird modified by Mazzarol, Volery, Doss, and Thein (1999) states that entrepreneurial intention is determined by characteristics and environment. Characteristics includes traits and background. Meanwhile, environment includes social, politics, economy, and infra structure development. Entrepreneurial characterisctics is a combination of some characteristics that will determine whether someone can be called an entrepreneur (Gartner, 1989). Previous researchers have studied entrepreneurial characterisctics dan entrepreneurship writers have mentioned the entrepreneur's characterisctics. This study is trying to analyze the characteristics that have been studied by the previous researchers. That is internal locus of control (Bonnet and Furnham,1991; Luthje and Franke, 2003; Rasheed, 2003; Birdthistle, 2008; Othman and Ishak, 2009), need for achievement (Bonnett and Furnham, 1991; Rasheed, 2003; Yusof, Sandhu and Jain, 2007; Taormina and Lao, 2007; Indarti and Rostiani, 2008; Othman and Ishak, 2009; Hatten and Ruhland, 1995), propensity to risk (Sexton and Bowman,1985; Luthje and Franke, 2003; Yusof, Sandhu and Jain, 2007), creativity (Birdthistle, 2008), social networking (Taormina and Lao, 2007; Chen, Weng and Hsu, 2010) and tolerance for ambiguity (Yusof, Sandhu and Jain, 2007).

The relationship of entrepreneurial characterisctics and entrepreneurial intention has been studied by previous researchers. Indarti and Rostiani (2008) stated that characteristics, instruments, and demographic factor determine entrepreneurial intention. Birdthistle (2008) stated that locus of control and importance of independence that consists of leisure time, creativity, solution orientation and safety orientation are important 
to someone who decides to be an entrepreneur as his choice of career. McClelland in Kobia and Sikalieh (2010) stated that need for achievement pushes people to look for entrepreneural jobs. Begley (1995) stated that propensity to risk shows the difference of business founders and the ones who are not. Thus, someone with entrepreneurial characterisctics has a tendency to establish a new business in the future.

Ajzen (2005) defines an attitude as a disposition to respond favorably or unfavorably to an object, person, institution or events. someone's attitude related to his evaluation to an object. If he thinks that the object will give him a benefit, he will do the necessary action. On the contrary, if he thinks that the object will not give him any benefit, he will not do any action. The relationship of attitude and intention is described in Theory Planned of Behavior. It states that intention is determined by individual's attitude toward the behavior, subjective norm, and perceived behavioral control (Ajzen, 1991; Ajzen, 2005). So, attitude is one of intention predictors. This study defines entrepreneurial attitude as a tendency to give a positive or negative response to entrepreneurship. Someone who has a respect to entrepreneurship may establish a new business in the future. Luthje dan Franke (2003) stated that entrepreneurial attitude has a strong and significant influence on entrepreneutial intention. This study examines the relationship among entrepreneurial characterisctics , entrepreneurial attitude, and entrepreneurial intention.

\subsection{Entrepreneurial characterisctics}

\section{Literature Review}

Entrepreneurial characterisctics is a combination of some characteristics that should be owned by an entrepreneur (Gartner, 1989; Basu and Altinay, 2002) and some psychological attributes are regarded as predictor of entrepreneurial intention (Rasheed, 2003). This study analyzes entrepreneurial characterisctics that consists of locus of control, need for achievement, propensity to risk, creativity, social networking, and tolerance for ambiguity.

\subsubsection{Internal Locus of control}

Someone who tends to have internal locus of control believes that his personal deed will influence the result of what he does (Rotter, 1966 in Lefton, 1985 and Rasheed, 2003). Kobia dan Sikalieh (2010) stated that an individual who tends to have internal locus of control feels that the result of what he does depends on his own behaviour or his own characteristics that is relatively permanent.

Students who tend to have internal locus of control respect entrepreneurship activities better than those who do not (Luthje dan Franke, 2003) and most Irish students of the third grade have internal locus of control, one of entrepreneurial characteristics (Birdthistle, 2008). Entrepreneurial attitude that is based on internal locus of control will motivate university graduates to choose entrepreneurship as their choice of career (Othman and Ishak, 2009)

\subsubsection{Need for achievement}

Someone's attention to an achievement is called the need for achievement. Need for achievement will make someone have better hopes or do something better or faster than other people or better than his previous achievement or than other previous people (McClelland, 1961). The need for achievement will push someone to look for an entrepreneural job to reach a higher achievement than another job (McClelland in Kobia and Sikalieh, 2010)

Need for achievement has a positive and significant influence on entrepreneurial tendency (Yusof, et al. (2007). The need for achievement correlates to entrepreneurial intention (Collins, Hanges and Locke, 2004; Taormina and Lao, 2007; Suan, Ai, Raman, Loon and Tanumihardja, 2011).

\subsubsection{Propensity to Risk}

One of entrepreneurial characterisctics is propensity to risk. It is readiness to take risks in doing activities or when the percentage of success is less than 100\% (Kuip dan Verheul, 2003).

Entrepreneurship activities have more risks than activities that are controlled by tradition e.g spiritual ceremony. But, it has less risks than gambling. A gambler does not have a knowledge used as a gambling decision (McClelland, 1961). Entrepreneurs are willing to take risks against uncertain moments but they expect a benefit as the reward of bearing the uncertainty (Lowe dan Marriott, 2006). Entrepreneurs are not people who are ready to take risks without any calculation but they are people who take risks based on calculation ( Zimmerer, et al., 2008). This study defines propensity to risk as a tendency that is not afraid to take risks but not as a risk taker at a very low degree or as a risk taker at a too high degree.

The characteristics of having propensity to risk is the character that differ business founders from those who do not (Begley, 1995). But, the character do not differ a new business founder from a manager (Brockhaus, 1980; Carland, Carland, Carland and Pearce, 1995). 


\subsubsection{Creativity}

Creativity is a process of an original response development, new and accurate to a problem. An original response is defined as something that has not existed before. Meanwhile, a news response is defined as something new or not artifial (Lefton, 1985). Creativity is defined as an ability to develop new ideas and to find new ways in seeing a problem and an opportunity (Zimmerer, et al., 2008). This study employs creativity definition by Zimmerer, et al. (2008).

An entrepreneur should be creative. Without creativity, someone will only become an ordinary merchant. Creativity is an important characteristic that should be owned by someone who decides to choose entrepreneurship as his choice of career (Birdthistle, 2008).

\subsubsection{Social networking}

Social networking is a tendency to have a relationship and to interact with other people. It is seen as a social behaviour and is regarded as a pshychological variable personality (Taormina and Lao, 2007). Chen, et al. (2010) states that social networking is related to the ability to manage relationship well to reach a success. Social networking plays a very important role in developing entrepreneurial intention and is an important factor of a success ( Zafar, Yasin dan Ijaz, 2012).

A number of researchers have known that social networking is one of entrepreneurial characteristics. It is positively correlated to the motivation of starting a new business (Taormina dan Lao, 2007). Chen, et al. (2010) states that most university students do not have social experience. They do not pay attention to social networking. In conclusion, they have a lower value in social networking than the entrepreneurial model. Thus, social networking is a tendency to like establishing and maintaining social relationship to ask for help, suggestions to reach a success.

\subsubsection{Tolerance for ambiguity}

Tolerance for ambiguity is a personal characteristic that influences the way of managing information about an ambiguous situation (Sexton and Bowman, 1985; Zimmerer, et al., 2008). In an extreme condition, ambiguity is like something that is not expected, full of pressure, and threatening. On the other side, tolerance for ambiguity is regarded as something expected and is a challenge to the goal (Sexton dan Bowman,1985). One of the characteristics of someone who is tolerant for ambiguity is that he will try to get more information to delete the ambiguity or to reduce the uncertainty (Zarei, Zainalipour dan Shahraki, 2013)

This study defines tolerance for ambiguity as a personality that influences the way to manage information about ambiguous situation (Zimmerer, et al., 2008). Tolerance for ambiguity is related to the entrepreneurial inclination (Yusof, et al., 2007). Thus, tolerance for ambiguity is an important characteristic to someone who decides to choose entrepreneurship as his choice of career because challenges and potentials of success in a new business are unpredictable.

\subsection{Theory of Planned Behavior}

Theory of Planned Behavior states that intention is as the function of attitude toward the behaviour, subjective norm dan perceived behavioral control (Ajzen, 1991; Ajzen, 2005). Attitude toward the behaviour is the individual's positive or negative evaluation of performing the particular behavior of interest. Subjective norm is someone's perception to a social pressure to do or not to do the behavior under consideration. Perceived behavioral control is self-efficacy or the ability to do the behavior of interest. Figure 2.1 explains Theory of Planned Behavior in the form of a diagram. This study focuses on the attitude toward the behaviour as the intention predictor because it focuses on the study of attitude and the development of positive way of thinking about entrepreneurship as the choice of career.

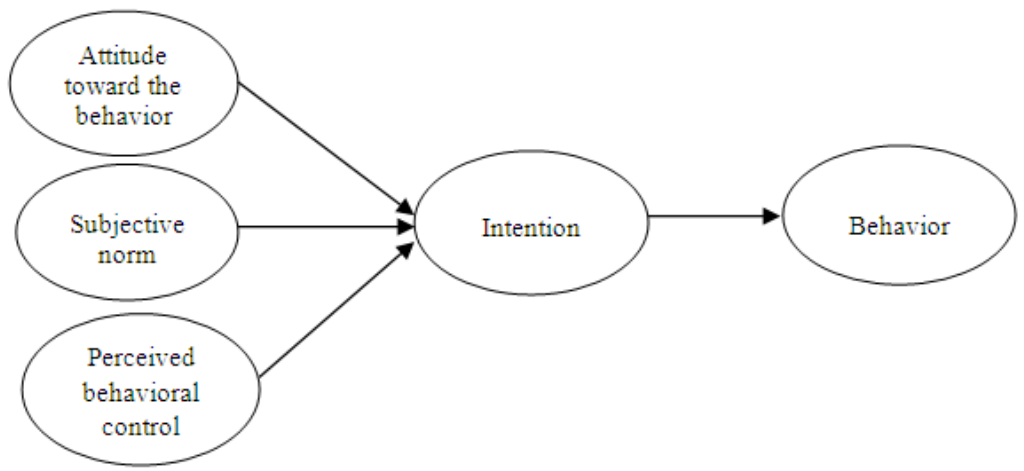

Figure 1: Theory of planned behavior (Ajzen, 1991; Ajzen, 2005) 


\subsection{Entrepreneurial Attitude}

Ajzen (2005) defines attitude as a tendency to react positively or negatively to an object, people, institution, or a moment. This study defines entrepreneurial attitude as a tendency to react positively or negatively to entrepreneurship. Students who tend to have internal locus of control develop positive attitude to entrepreneurship after attending SBI programme (Hatten dan Ruhland, 1995). Other researchers Luthje and Franke (2003) and Fini, Grimaldi, Marzocchi and Sobrero (2009) state that attitude has a direct influence to entrepreneurial intention.

\subsection{Entrepreneurial Intention}

Intention is an indication about how hard someone tries to do a behaviour, and how strong his effort to do a certain behaviour (Ajzen, 1991). Entrepreneurial intention is aimed to creating a new business or new values in the existing business (Bird, 1988). Fini, et al. (2009) state that entrepreneurial intention is as a cognitive representation of actions to be implemented by individuals to either establish a new independent ventures or to create new value within existing company.

This study defines entrepreneurial intention as a cognitive representation of actions that will be done by someone to establish a new business.

Some factors are regarded as the determiners of entrepreneurial intention. Bird (1988) states that personal characteristic factors and the environment determine entrepeneurial intention. Bird's Conception of contexts of entrepreneurial intentionality modified by Mazzarol, et. al. (1999) state that personal factors include traits and individual background. Environment factor includes social, economy, politics, and infra structure development. Indarti dan Rostiani (2008) states that personality, environment, and demography are the determiners of entrepreneurial intention. Luthje dan Franke (2003) states that entrepreneurial attitude has a strong and significant influence on entrepreneurial intention.

\subsection{The relationships among entrepreneurial characterictics, entrepreneurial atitude, and entrepreneurial intention}

Entrepreneurial characterictics are some characterictics that mark someone to be called an entrepreneur (Gartner, 1999). Entrepreneurial intention is a cognitive representation of actions to be implemented by individuals to either establish a new independent ventures or to create new value within existing company (Fini, et al., 2009). This study defines entrepreneurial intention as a cognitive representation of actions that will be done by college/university students to establish a new business.

Some psychological characteristics are important to entrepreneurship career. Someone who decides to choose entrepreneurship as his choice of career should have internal locus of control (Rotter in Shane, et al., 2003); need for achievement (McClelland in Kobia dan Sikalieh, 2010); creativity (Birdthistle, 2008); social networking (Taormania and Lao, 2007); propensity to risk (Begley, 1995); tolerance for ambiguity (Sexton and Bowman, 1985). Thus, someone who has entrepreneur's characterictis tend to establish a new business in the future.

Attitude is evaluative. Attitude is defined as someone's tendency to give a certain response to a certain object. Theory of Planned Behaviour states that attitude is one of intention predictors (Ajzen, 1991; Ajzen, 2005). Entrepreneurial attitude is students' tendency to entrepreneurship. Students will respect entrepreneurship if they think that it gives them a benefit. On the contrary, they will not respect it if they think that it does not give them any benefit. Othman and Ishak (2009) state that the three components of characteristics (internal locus of control, monetary value and autonomy) are significant in motivating university graduates to choose entrepreneurship as their choice of career. Lutjhe dan Franke (2003) state that internal locus of control and willing to take risks has a positive and significant influence to entrepreneurial attitude has a positive and significant influence on entrepreneurial intention. Thus, the hypothesis proposed is that entreprenurial characterictics act as mediator of entrepreneurial characteristics influence on entrepreneurial intention.

\subsection{Data}

\section{Methods}

The data were collected from a number of first-semester students to the final-semester students of The State Polytechnic of Malang and Brawijaya University who have learned an entrepreneurial education. Judgment sampling was used to choose the sample. Questionaieres were used to collect the data. Linkert Scale 1 to 5 was put on each instrument item. Notes: $1=$ strongly disagree, $2=$ disagree $3=$ fairly agree $4=$ agree 5 $=$ strongly agree. The number of data processed are 206. The data were analyzed by using descriptive statictics and path Analysis. Data processing was done by using GeSCA (Hwang, 2011) 


\subsection{Identifying Variable Indicators}

Entrepreneurial characterictics is as the second-order variable that has six dimensions: internal locus of control, need for achievement, propensity to risk, creativity, social networking dan tolerance for ambiguity. TABLE 1 shows the value of $C R>2$. The result shows that all the dimensions of entrepreneurial characteristics has a contribution to explain about entrepreneurial characteristics. Creativity dimension has the highest contribution in explaining the variable of entrepreneurial characteristics followed by need for achievement, social networking, tolerance for ambiguity, propensity to risk dan internal locus of control.

Table 1. Loading Value of $2^{\text {nd }}$-order and Average Value of Dimension of Entrepeneurial characteristics

\begin{tabular}{|c|c|c|c|c|}
\hline \multirow{2}{*}{\multicolumn{2}{|c|}{$2^{\text {nd }}$-order Variable }} & \multicolumn{3}{|c|}{ Weight } \\
\hline & & Estimate & SE & $\mathrm{CR}$ \\
\hline \multicolumn{5}{|c|}{ Entrepreneurial Characteristics } \\
\hline 1. & Internal Locus of Control & 0.170 & 0.021 & 8.018 \\
\hline 2. & Need for achievement & 0.242 & 0.024 & 10.241 \\
\hline 3. & Propensity to risk & 0.210 & 0.022 & 9.403 \\
\hline 4. & Creativity & 0.269 & 0.035 & 7.608 \\
\hline 5. & Social networking & 0.237 & 0.023 & 10.309 \\
\hline 6. & Tolerance for ambiguity & 0.216 & 0.027 & 8.060 \\
\hline
\end{tabular}

TABLE 2 shows that the dimensions indicator of entrepreneurial characteristics give significant contribution to explain all the dimensions of entrepreneurial characteristics. The average score of each indicator goes from 3 to 5 .

Table 2 Loading Value and Average Value of Dimension Indicator of Entrepreneurial Characteristics

\begin{tabular}{|c|c|c|c|c|}
\hline \multirow[t]{2}{*}{ Indicator } & \multicolumn{3}{|c|}{ Loading } & \multirow[b]{2}{*}{ Average } \\
\hline & Estimate & SE & CR & \\
\hline \multicolumn{5}{|l|}{ Internal of Locus of Control } \\
\hline Working hard to reach the goal & 0.772 & 0.050 & $15.56^{*}$ & 4.524 \\
\hline Working hard to reach success in life & 0.744 & 0.058 & $12.85^{*}$ & 4.335 \\
\hline Believing that not working hard is the cause of failure & 0.595 & 0.088 & $6.74^{*}$ & 3.748 \\
\hline Working hard to reach achievement & 0.615 & 0.062 & $9.96^{*}$ & 3.927 \\
\hline \multicolumn{5}{|l|}{ Need for achievement } \\
\hline Motivation to reach present achievement & 0.717 & 0.059 & $12.2^{*}$ & 4.529 \\
\hline Motivation to reach future achievement & 0.812 & 0.049 & $16.51^{*}$ & 4,626 \\
\hline Motivation to do the job & 0.736 & 0.042 & $17.51^{*}$ & 4.126 \\
\hline $\begin{array}{l}\text { - } \\
\text { people }\end{array}$ & 0.712 & 0.044 & $16.28^{*}$ & 4.010 \\
\hline \multicolumn{5}{|l|}{ Propensity to risk } \\
\hline $\begin{array}{l}\text { Calculating the advantages and the disadvantages in } \\
\text { the decision making }\end{array}$ & 0.690 & 0.056 & $12.41^{*}$ & 4.058 \\
\hline $\begin{array}{l}\text { Willing to take the risks as the result of the decision } \\
\text { he/she has made }\end{array}$ & 0.834 & 0.035 & $23.81^{*}$ & 4.068 \\
\hline Willing to take the risk as the result of what he/she did & 0.866 & 0.020 & $42.57^{*}$ & 4.087 \\
\hline $\begin{array}{l}\text { - Willing to take risks based on the degree ofthe } \\
\text { achievement }\end{array}$ & 0.629 & 0.068 & $9.29^{*}$ & 4.087 \\
\hline \multicolumn{5}{|l|}{ Creativity } \\
\hline Developing other ways & 0.670 & 0.056 & $12.02^{*}$ & 3.995 \\
\hline Developing different views & 0.733 & 0.043 & $17.03^{*}$ & 4.005 \\
\hline Developing new ideas & 0.773 & 0.043 & $17.92^{*}$ & 3.840 \\
\hline Developing alternatives to solve problems & 0.764 & 0.037 & $20.58^{*}$ & 3.961 \\
\hline
\end{tabular}

Table 2 (Continued)

\begin{tabular}{|l|c|c|c|c|}
\hline \multicolumn{2}{|c|}{ Indicator } & \multicolumn{2}{c|}{ Loading } & \multirow{2}{*}{ Average } \\
\cline { 2 - 5 } & Estimate & SE & \multicolumn{1}{c|}{ CR } & \\
\hline Social networking & & & & \\
\hline$\bullet \quad$ The ability to establish social networking & 0.782 & 0.041 & $18.96^{*}$ & 4.364 \\
\hline$\bullet \quad$ The ability to make friends & 0.637 & 0.059 & $10.84^{*}$ & 3.699 \\
\hline$\bullet \quad$ The ability to ask for help and suggestions & 0.674 & 0.055 & $12.19^{*}$ & 3.874 \\
\hline$\bullet \quad$ Maintaining social networking & 0.817 & 0.036 & $22.65^{*}$ & 4.252 \\
\hline Tolerance for Ambiguity & & & & \\
\hline
\end{tabular}


The Relationships among Entrepreneurial Characteristics, Entrepreneurial Attitude, ....

\begin{tabular}{|ll|c|c|c|c|}
\hline$\bullet$ & Adjusting with unpredictable moments & 0.603 & 0.069 & $8.73^{*}$ & 3.534 \\
\hline$\bullet$ & Considering new information & 0.798 & 0.029 & $27.99^{*}$ & 3.913 \\
\hline$\bullet$ & Awareness to the possibility of uncontrollable plan & 0.685 & 0.071 & $9.69^{*}$ & 3.869 \\
\hline$\bullet$ & Collecting and managing information & 0.696 & 0.060 & $11.69^{*}$ & 4.078 \\
\hline
\end{tabular}

For internal locus of control, only indicators of "hard work to reach the goal" and "hard work to reach the success of life" are confirmed in the "agree area". For need for achievement, all indicators are confirmed in the "agree area'. For propensity to risk, all indicators are confirmed in the "agree area". For creativity, only indicator of "the ability to see a problem from different views" are confirmed in the "agree area". For social networking, only indicators "the ability of establishing a social relationship" and "the ability of maintaining social relationship" are confirmed in the "agree area". For tolerance for ambiguity, only the indicator of "collecting and managing information" are confirmed in the "agree area". Thus, the role model on entrepreneurship education by focusing on the importance of internal locus of control, social networking, creativity and tolerance for ambiguity should be done to increase the students' entrepreneurial characterictis.

TABLE 3 shows that all indicators have a contribution to explain the variables of entrepreneurial attitude and entrepreneurial intention. The indicator of "like becoming the boss for my own business", "like working at flexible working schedule", "like working hard to start a business" are confirmed in the "agree area". For the indicator of entrepreneurial intention, the indicator of "motivation to establish a business in the future", "motivation to realize a business idea ", "motivation to establish a business after having a capital", and "motivation to establish a business based on social networking" are confirmed in the "agree area".

Table 3 Loading Value and the AverageValue of Indicator of Entrepreneurial attitude and Entrepreneurial Intention

\begin{tabular}{|c|c|c|c|c|}
\hline \multirow[t]{2}{*}{ Indicators } & \multicolumn{3}{|c|}{ Loading } & \multirow[t]{2}{*}{ Average } \\
\hline & Estimate & SE & CR & \\
\hline \multicolumn{5}{|l|}{ Entrepreneurial Behaviour } \\
\hline Motivation to be the boss of his own business & 0.698 & 0.054 & $12.96^{*}$ & 4.349 \\
\hline Motivation to work at a flexible working schedule & 0.711 & 0.057 & $12.55^{*}$ & 4.087 \\
\hline Motivation to attend entrepreneurship activities & 0.798 & 0.031 & $25.38^{*}$ & 3.845 \\
\hline Willing to work hard to start a new business & 0.736 & 0.044 & $16.61^{*}$ & 4.015 \\
\hline \multicolumn{5}{|l|}{ Entrepreneurial Intention } \\
\hline $\begin{array}{l}\text { - } \\
\text { graduation }\end{array}$ & 0.740 & 0.053 & $14.0^{*}$ & 3.966 \\
\hline Motivation to establish a business in the future & 0.872 & 0.022 & $40.38^{*}$ & 4.306 \\
\hline Motivation to realize a business & 0.875 & 0.026 & $34.21^{*}$ & 4.053 \\
\hline $\begin{array}{l}\text { Motivation to establish a business after having } \\
\text { financial capital }\end{array}$ & 0.151 & 0.154 & 0.98 & 4.063 \\
\hline $\begin{array}{l}\text { - Motivation to establish a business based on social } \\
\text { networking }\end{array}$ & 0.535 & 0.082 & $6.49^{*}$ & 4.403 \\
\hline
\end{tabular}

\section{Findings}

The analysis results of entrepreneurial attitude as a mediator of entrepreneurial characterictics influence on entrepreneurial intention as follows.

1. The analysis result by involving mediation variable is displayed in TABLE 4 and Figure 2. The result shows that:

- The influence of entrepreneurial characterictics on entrepreneurial attitude is sifnificant with coefficient 0.433 at significance level 0.05 .

- The influence of entrepreneurial attitude on entrepreneurial intention is significant with coefficient 0.504 at significance level 0.05 .

- The influence of entrepreneurial characterictics on entrepreneurial intention is significant with coefficient 0.231 at significance level 0.05 .

Table 4. The Result of Path Analysis by Involving Mediation Variable

\begin{tabular}{|l|l|c|c|}
\hline Independent Variable & Dependent Variable & $\begin{array}{l}\text { Path } \\
\text { Coefficient }\end{array}$ & $\begin{array}{c}\text { Critical } \\
\text { Ratio }\end{array}$ \\
\hline Entrepeneurial characteristics & Entrepeneurial Attitude & 0.433 & $4.85^{*}$ \\
\hline Entrepeneurial characteristics & Entrepeneurial Intention & 0.231 & $2.54^{*}$ \\
\hline Entrepeneurial attitude & Entrepeneurial Intention & 0.504 & $7.84^{*}$ \\
\hline
\end{tabular}




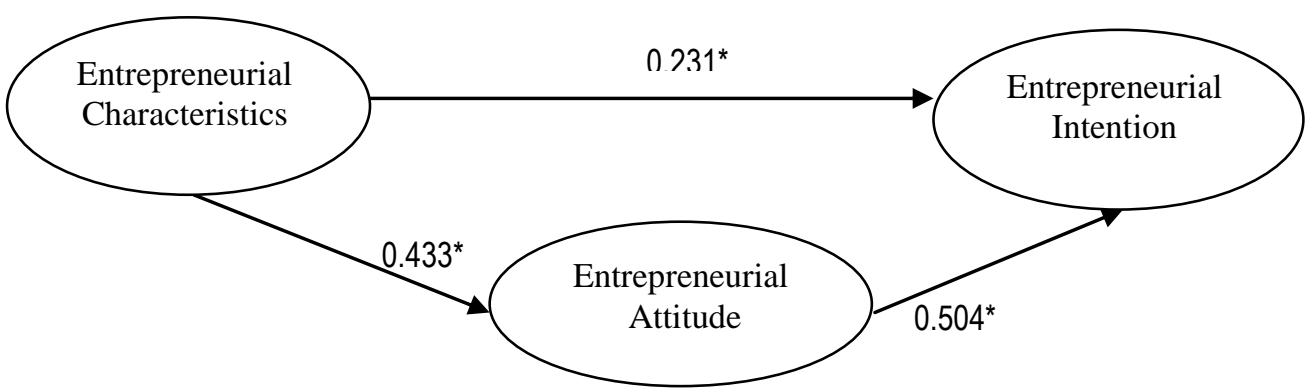

Figure 2: Analysis on the influence of entrepreneurial characteristics on the entrepreneurial intention by involving mediation variable.

2. The analysis result of entrepreneurial characterisctics influence on entrepreneurial intention without involving mediation variable shows that entrepreneurial characteristic has a significant influence on entrepreneurial intention with coefficient 0.547 (TABLE 5 and Figure 3)

Table 5 The Result of Path Analysis Without Involving Mediation Variable

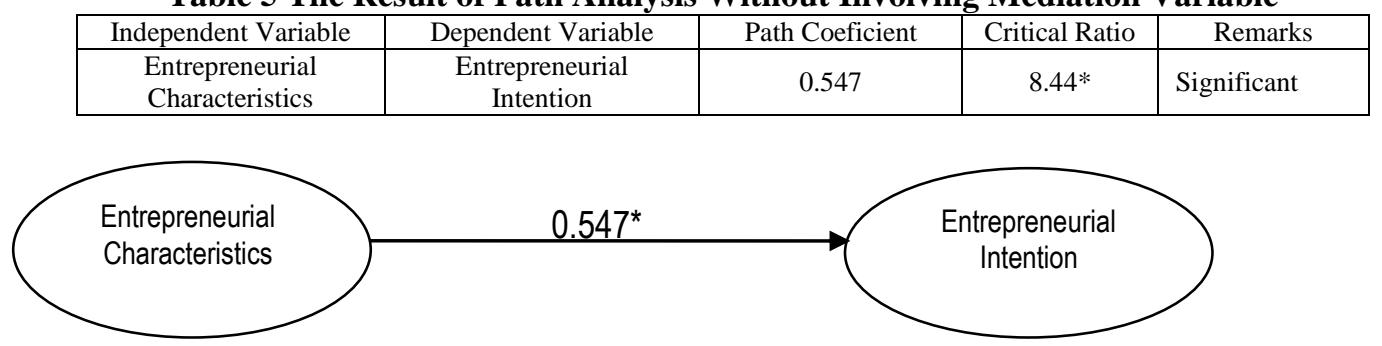

Figure 3 Analysis of entrepreneurial characteristics influence on entrepreneurial intention without mediation variable

Based on the analysis showing that the entrepreneurial characterictis has a significant influence on the entrepreneurial attitude, dan entrepreneurial attitude has a significant influence on entrepreneurial intention. The coefficient of entrepreneurial characteristics influence on entrepreneurial intention through an analysis by involving variable mediation is smaller than the coefficient of entrepreneurial characteristics influence on entrepreneurial intention without involving mediation variable $(0.231<0.547)$. Based on that analysis, it can be concluded that entrepreneurial attitude can be regarded as a partial mediation.

Thus, the hypothesis stating that entrepreneurial attitude as a mediator of entrepreneurial characterictis influence on entrepreneurial intention can be proved.

\section{Discussion}

The analysis result shows that entrepreneurial attitude acts as a partial mediation entrepreneurial characterisctics influence on entrepreneurial intention. It means that the influence of entrepreneurial characterisctics on the entrepreneurial intention is not totally explained by entrepreneurial attitude. Meanwhile Baron and Kenny (1986) stated that entrepreneurial attitude acts as a reinforcing entrepreneurial characterisctics influence on entrepreneurial intention.

The Finding shows that students who have entrepreneurial characterisctics tend to establish new entrepreneurship in the future. The result is in line with Bird's concept (1988) modified by Mazzarol, et al. (1999) that states personality is one of factors that determines the entrepreneurial intention. Further, Birfthistle (2008) states that characteristics of locus of control and importance of independence are important to someone who wants to be an entrepreneur. Indarti dan Rostiani (2008) state that personal characteristics determines students' entrepreneurial intention. Then, entrepreneurial characteristics has a significant influence on entrepreneurial attitude. It means that students who have internal locus of control, need for achievement, propensity to risk, creativity, social networking, and tolerance for ambiguity tend to like becoming bosses for their own businesses and like having flexible working schedules. That finding confirms the result of the study stating that risk taking propensity and internal locus of control has a significant influence on entrepreneurial attitude (Luthje dan Franke, 2003; Hatten dan Ruhland, 1995). Risk taking, innovativeness, need for achievement and tolerance for ambiguity has a significant influence on entrepreneurial attitude (Yusof, et. al., 2007). Harris dan Gibson (2008) states that students' characterictics are related to entrepreneurial attitude. Next result of the study also shows that entrepreneurial attitude has a significant influence on entrepreneurial intention. It means that students who like becoming bosses for their own businesses tend to realize their 
business ideas in the future. This finding confirms Ajzen's theory (2005) stating that attitude is the intention predictor. Besides, it also confirms stating that entrepreneurial attitude has a strong and significant influence on entrepreneurial intention (Luthje and Franke, 2003; Fini, Grimaldi, Marzocchi and Sobrero, 2009).

Thus, the students' intention to realize their business in the future is determined by entrepreneurial attitude based on the students' entrepreneurial characteristics. Besides, the students' entrepreneurial intention is also directly influenced by the students' entrepreneurial characterictics. Future research can consider environment factors (e.g. entrepreneurial education and access modal) as a determinant of student's entrepreneurial intention

\section{References}

[1]. Ajzen, I. 1991. The Theory of Planned Behavior. Organizational Behavior and Human Decision Process. Vol.50 p.179-211

[2]. Ajzen, I. 2005. Attitude, Personality and Behaviour. Second Edition. Open University Press.

[3]. Baron, R.M. and Kenny, D.A. (1986). The Moderator-Mediator Variable Distinction in Social Psychological Research: Conceptual, Strategic, and Statistical Considerations. Journal of Personality and Social Psychology. Vol. 51 No. 6 p.1173-1182

[4]. Basu, A. and Altinay, E. 2002. The interaction between culture and entrepreneurship in London's immigrant Business. International Small Business Journal. Vol.20 No.4 p.371-393

[5]. Begley, T. M. (1995). Using founder status, age of firm, and company growth rate as the basis for distinguishing entrepreneurs form managers of smaller businesses. Journal of Business Venturing. Vol.10 No.3 p.249-263.

[6]. Bird, B. 1988. Implementing Entrepreneurial Ideas: The Case for Intention. Academy of Management Review. Vol.13 No.3 p.442453.

[7]. Birdthistle, N. 2008. An examination of tertiary students' desire to found an enterprise. Education + Training. Vol.50 No.7

[8]. Bonnett, C. and Furnham. A. 1991. Who wants to be an entrepreneur? A study of adolescents interested in a young Enterprise scheme. Journal of Economic Psychology. Vol.12 p. 465-478. North-Hollan

[9]. Brockhaus, R.H. 1980. Risk Taking Propensity of entrepreneurs. Academy of Management Journal, Vol.23 No.3 p. $509-520$

[10]. Carland, J.W. III, Carland, J.W., Carland, J.A., and Pearce, J.W. (1995). Risk taking propensity among entrepreneurs, small business owners and managers. Journal of Business and Entrepreneurship. Vol.7 No.1.p.12-23.

[11]. Chen, W., Weng, C.S. and Hsu, H. 2010. A Study of the entrepreneurship of Taiwanese youth by the Chinese Entrepreneur Aptitude Scale. Journal of Technology Management in China. Vol.5 No.1.p.26-39

[12]. Collins, C.J., Hanges, P.J. and Locke, E.A. 2004. The Relationship of Achievement Motivation to Entrepreneurial Behavior: A Meta-Analysis. Cornell University ILR School. Vol.17 No.1. p.95-117

[13]. Directorate General of Higher Education, The Ministry of National Education, 2010. Guide of Student Entrepreneur Program. Jakarta

[14]. Fini, R., Grimaldi, R., Marzocci, G. L. and Sobrera, M. 2009. The Foundation of Entrepreneurial Intention. Paper to be presented at the Summer Conference on Copenhagen Business School.

[15]. Gartner, B. W. 1989. "Who is an Entrepreneurs?" Is the Wrong Quection. University of Baltimore Educational Foundation.

[16]. Harris, M.L. and Gibson, S.G. 2008. Examining the entrepreneurial attitudes of US business students. Education + Training. Vol. 50 No.7 p. $568-581$

[17]. Hatten, T. S. and Ruhland, S. K.. 1995. Student attitude toward entrepreneurship as affected by participation in n SBI program. Journal of Education for Business. Vol. 70 No.4.

[18]. Hwang, H. 2011. GeSCA User’s Manual.

[19]. Indarti, N. dan Rostiani, R. 2008. Intensi Kewirausahaan Mahasiswa: Studi Perbandingan Antara Indonesia, Jepang dan Norwegia, Jurnal Ekonomika dan Bisnis Indonesia. Vol.23 No.4

[20]. Kobia, M. and Sikalieh, D. 2010. Towards a search for the meaning of entrepreneurship, Journal of European Industrial Training, Vol. 34 No.2 p.110-127

[21]. Kuip, I. and Verheul, I. 2003. Early development of entrepreneurial qualities: the role of initial education. SCALES-paper N200311. EIM Business \& Policy Research, Zoetermeer.

[22]. Lefton, L. A. 1985. Psychology. Third Edition. Allyn and Bacon, Inc. Massachusetts.

[23]. Lowe, R. and Marriott, S. 2006. Enterprise: Entrepreneurship and Innovation Concepts, Contexts and Commercialization. First edition. Elsevier Ltd. Burlington

[24]. Luthje, C. and Franke N. 2003. The 'making' of an entrepreneur: testing a model of entrepreneurial intent among engineering students at MIT. R\&D Management. Vol.33 No.2

[25]. Mazzarol, T., Volery, T., Doss, N. and Thein, V. 1999. Factors influencing small business start-ups. International Journal of Entrepreneurial Behaviour \& Research. Vol.5 No.2 p.48-63

[26]. McClelland, D.C. (1961) The Achieving Society, Van Norstand, Princeton, NY.

[27]. Othman, H. N. and Ishak, S.B. 2009. Attitude Towards Choosing a Career in Entrepreneurship Amongst Graduates. European Journal of Social Sciences. Vol.10 No.3

[28]. Rasheed, H. S. 2003. Developing Entrepreneurial Characteritics in Youth: The Effects of education and Enterprise Experience. International Journal of Entrepreneurship education

[29]. Sexton, D. L. and Bowman, N. 1985. The Entrepreneur: A Capable Executive and more. Journal of Business Venturing. Vol.1 p.129-140

[30]. Shane, S., Locke, A. E., and Collins, C.J. 2003. Entrepreneurial motivation. Human Resource Management Review. Vol.13 p.257279

[31]. Suan, C.T., Ai, Y.J., Raman, K., Loon, K.w. and Tanumiharja J. 2011. Entrepreneurial Intentions Among University Students. Business \& Management Quarterly Review. Vol.2 No.3 p.33-38

[32]. Taormina, R. J. and Lao, S.K. 2007. Measuring Chinese entrepreneurial motivation: Personality and environmental influences. International journal of Entrepreneurial Behaviour \& Research. Vol.13 No.4 p.200-221.

[33]. Yusof, M., Sandhu, M.S. and Jain, K.K. 2007. Relationship Between psychological characteristics and entrepreneurial inclination : A Case Study of Student at University Tun Abdul Razak (UNITAR). Journal of Asia Entrepreneurship and Sustainability. Vol.111 No.2

[34]. Zafar, M.J., Yasin, G. and Ijaz, M. 2012. Social Networking a Source Developing Entrepreneurial Intentions Among Untrepreneurs: A Case of Multan. Asean Economic and Financial Review. Vol.2 No.8

[35]. Zarei, E., Zainalipour, H. and Shahraki. L.S. 2011. Relationship between Achievement Motivation and Ambiguity Tolerance with Entrepreneurship among Students in Hormozgan. Journal of Educational and Management Studies. Vol.3 No.2 p.167-172 